\title{
The impact of feeding a high-fibre and high-fat concentrated diet on the recovery of horses suffering from gastric ulcers
}

\author{
Stephanie Böhm', Thomas Mitterer ${ }^{2}$ and Christine Iben' \\ ${ }^{1}$ Department for Farm Animals and Veterinary Public Health, Institute of Animal Nutrition and Functional Plant Compounds, University of Veterinary Medicine \\ Vienna, Austria \\ 2 Tierklinik Mitterndorf, Rosenweg 2, 3452 Mitterndorf, Austria
}

\begin{abstract}
Summary: The objective of this study was to find out whether a change from a grain-rich concentrated feed to a grain-free, fibre- and fatenriched concentrated diet (FFD), leads to an improvement in gastric ulcers in horses. The experiment was conducted as a prospective experimental study. Thirty-four adult horses with gastric lesions - six mares and 28 geldings - fulfilled the inclusion criteria of this study. The average age was $11 \pm 4$ (mean \pm SD) years and the horses weighed between $358 \mathrm{~kg}$ and $697 \mathrm{~kg}$. Twenty horses were fed the FFD, while 14 horses were controls (C) and received their usual concentrated feed. Each horse underwent gastroscopy twice, at an interval of eight weeks. An independent evaluation of the examination and the scoring of the lesions, using the Equine Gastric Ulcer Council 0-4 scoring system for equine gastric ulcer syndrome (EGUS), was performed by an experienced gastroscopist. The horses with EGUS scores $\geq 3$ received additional omeprazole at the recommended dosage for 14 days. The horses of the FFD group were adapted to the new diet whereas the control group received their usual concentrate. In the control group, only the amounts of hay and concentrate were adjusted to the requirement of the respective horse. After the change of the ration, the starch intake (FFD $0.09 \pm 0.05 \mathrm{~g} / \mathrm{kg} \mathrm{BW;} \mathrm{C} 1.38 \pm 0.62 \mathrm{~g} / \mathrm{kg} \mathrm{BW}$ ) was significantly different. However, there was no difference concerning the hay intake (FFD $21.2 \pm 3.5 \mathrm{~g} / \mathrm{kg} \mathrm{BW} / \mathrm{day} ; \mathrm{C} 23.3 \pm 5.1 \mathrm{~g} / \mathrm{kg}$ BW/day), the Ca intake (FFD $0.129 \pm 0.034 \mathrm{~g} / \mathrm{kg} \mathrm{BW/day;} \mathrm{C} 0.112 \pm 0.019 \mathrm{~g} / \mathrm{kg} \mathrm{BW} /$ day), the Mg intake (FFD $0.042 \pm 0.009 \mathrm{~g} / \mathrm{kg}$ BW/day; C $0.042 \pm 0.011 \mathrm{~g} / \mathrm{kg} \mathrm{BW/day)}$ or the intake of the praecaecal digestible protein (FFD $1.42 \pm 0.38 \mathrm{~g} / \mathrm{kg} B W / \mathrm{day}$; C $1.58 \pm 0.39 \mathrm{~g} / \mathrm{kg} \mathrm{BW} /$ day). The prevalence and severity of the mucosal lesions significantly decreased in the FFD group ( $p<0.001)$. No significant correlation between the EGUS and the other risk factors, such as workload, behaviour or typical symptoms was found in this study. The change of the concentrated feed to FFD improved the gastric ulcerations in both squamous and glandular mucosa.
\end{abstract}

Keywords: horse, EGUS, gastric, ulcer, concentrate, feeding, nutrition

Citation: Böhm S., Mitterer T., Iben C. (2018) The impact of feeding a high-fibre and high-fat concentrated diet on the recovery of horses suffering from gastric ulcers. Pferdeheilkunde 34, 237-246; DOI 10.21836/PEM20180304

Correspondence: Mag. med. vet. Stephanie Böhm, Tierklinik Mitterndorf, Rosenweg 2, 3452 Mitterndorf, Austria; vetmed.boehm@gmail.com

\section{Introduction}

The gastric mucosal lesions, also known as equine gastric ulcer syndrome (EGUS), occur with a prevalence of 53-93\% in horses (Hammond et al. 1986, Vatistas et al. 1994, Murray et al. 1996) and often lead to poor performance by the animal. Tamzali et al. (2011) found gastric lesions in 93\% of the highlevel endurance horses during the competition season. In a group of 80 military horses in Brazil, $45 \%$ suffered from gastric ulcers (Aranzales et al. 2012). Another researcher found different degrees of gastric ulceration in $40 \%$ of 60 examined horses which did not show any clinical symptoms and in $59 \%$ of 48 horses with mild symptoms, like weight loss, poor body condition or reduced appetite (Niedzwiedz et al. 2013).

In Canada, a study of 94 thoroughbred horses revealed EGUS in $74.5 \%$ of the examined horses (Marques et al. 2011). The prevalence of EGUS in foals ranges between 30 and $50 \%$ (Andrews et al. 1999) particularly in weanlings (Dahlkamp et al. 2012). Before weaning, Dahlkamp et al. (2012) found gastric ulcers in 38 out of 79 foals they examined. After weaning, the number of affected foals, as well as the severity, increased significantly. A lot of studies have demonstrated the risk factors for ulceration. Equine gastric ulcer syndrome is often related to non-steroidal anti-inflammatory drug administration; but it is also considered to be stress-related, triggered by transport (McClure et al. 2005) or increased workload (Bell et al. 2007, Dionne et al. 2003, Jonsson and Egenvall 2006, Tamzali et al. 2011) and high starch diet (Nadeau and Andrews 2009, Luthersson et al. 2009b).

The management of feeding and diet play important roles in ulcer development. In a population of 201 Danish horses from 23 different stables, Luthersson et al. (2009b) diagnosed gastric ulceration in $53 \%$ (number of lesions $\geq 2[0-4]$, severity $\geq 2[0-5])$. The described risk factors included the intake of more than $2 \mathrm{~g}$ of starch per $\mathrm{kg}$ body weight (BW)/day or more than $1 \mathrm{~g}$ of starch per $\mathrm{kg} \mathrm{BW} /$ meal, straw as a single source of roughage, no water on the pasture, and periods of roughage deprivation of more than six hours (Luthersson et al. 2009b).

Equine gastric ulcer syndrome is not always associated with typical symptoms. In previous publications (Murray et al. 1989, The Equine Gastric Ulcer Council 1999, Venner et al. 2001, Jonsson and Egenvall 2006, Murray 2009, Hepburn 2014), a broad spectrum of symptoms was described, including reduced appetite, poor coat, bruxism, yawning, flehmen, recurrent colic, poor performance and body condition, changes in temperament due to pain and discomfort, and a decline in performance. 
Depending on the location of the lesions, Equine Squamous Gastric Disease (ESGD), affecting the squamous mucosa is distinguished from the Equine Glandular Gastric Disease (EGGD), where the lesions are found in the glandular mucosa and the pylorus (Merritt 2009). Equine Glandular Gastric Disease is not as well-described (Sykes and Jokisalo 2015) and has a worse response to medical treatment (Sykes et al. $2014 a, c$, Sykes et al. 2015b).

The drug of choice for the treatment of EGUS is omeprazole at a dosage of $4 \mathrm{mg} / \mathrm{kg}$ bodyweight once daily for at least 28 days per os (Andrews et al. 1999); but also, lower doses of 2 $\mathrm{mg} / \mathrm{kg}$ bodyweight and combinations with sucralfate have been found to be effective in the recent studies (Sykes et al, $2015 a, b$, Hepburn 2014). Scientific work on this subject is also focused on additives such as Saccharomyces cerevisiae and magnesium hydroxide (Sykes et al. 2014b), sea buckthorn berries and pulp (Huff et al. 2012), feed additives containing salts of organic acids in combination with B-vitamins (Hellings and Larsen 2014) or a pectin-lecithin complex (Sanz et al. 2014) for the treatment of gastric ulcers. The aim of the present study was to find out whether a grain-free diet with low starch and high fibre and fat content enriched with certain herbs can support the healing process of gastric ulcers in horses.

\section{Animals, material, and methods}

Feed

The tested diet (Mucovital prebiotic ${ }^{\circledR}$ by Mühldorfer Nutrition AG, Germany) is a grain-free, fibre- and fat-enriched concentrated diet (FFD), which was developed to maintain the digestive health, including gastric health, especially of sensitive horses. According to the producer's claim, it is a complete, premixed feed, which can regenerate the inflamed gastric mucosa through its unique combination of herbal ingredients. Table 1 shows the results of the sieve analysis.

\section{Composition of the FFD}

$41.1 \%$ alfalfa meal, $10.4 \%$ fruit (apple) pomace (dried), 10.2\% rice bran, 10\% alfalfa hay (gently dried), $5.5 \%$ lignocellulose, $5.0 \%$ sunflower seed kernels, $3.9 \%$ linseed extract powder, $2.6 \%$ milk thistle oil, $2.6 \%$ locust bean (chopped), $2.0 \%$ Jerusalem artichoke concentrate, $1.5 \%$ cane syrup, $1.0 \%$ calcium carbonate, $1.0 \%$ beetroot chips, $1.0 \%$ apple chips, $0.9 \%$ carrots (dried), $0.5 \%$ sodium chloride, $0.1 \%$ ginkgo leaves, $0.1 \%$ haw thorn leaves, $0.1 \%$ milk thistle, $0.1 \%$ artichoke, $0.1 \%$ dandelion. The difference to $100 \%$ is the proportion of premixes in the recipe $(0.3 \%)$.

\section{Nutritional additives (per $\mathrm{kg}$ )}

Vitamin A 14.000 I.U., vitamin D3 (E671) 800 I.U., vitamin E ( $\beta$-tocopheryl-acetate) $205.00 \mathrm{mg}$, iron (E 1, iron (II) sulphate) $140.00 \mathrm{mg}$, zinc (E6, zinc oxide) $120.00 \mathrm{mg}$, manganese (E5, manganese-(II)-oxide) $70.00 \mathrm{mg}$, copper (E4, cupric-(II)-sulphate) $20.00 \mathrm{mg}$, selenium (E8, sodium selenite) $0.35 \mathrm{mg}$, iodine (3b202, calcium iodate) $1.40 \mathrm{mg}$, cobalt (3b304) $0.15 \mathrm{mg}$, molybdenum (E7, sodium molybdat) $0.28 \mathrm{mg}$.
Analytical components of the FFD (\% of original substance; Futtermittellabor Rosenau, Wieselburg, Austria; values in brackets are according to the label)

Dry matter $91.4 \%$, crude protein 12.5 (12)\%, crude fat 8.2 (7.8) \%, crude fibre 25 (21.7)\%, crude ash 10.1 (8.8)\%, Nfree extracts $35.6 \%$, starch $4.6 \%$, neutral detergent fibre $55.0 \%$ (calculated), calcium 1.97 (1.5)\%, phosphorus 0.37 (0.5) \%, magnesium 0.24 (0.2) \%, potassium $1.3 \%$, sodium $0.09 \%$.

\section{Digestible energy}

9.6 MJ DE/kg (according to the label); Metabolisable energy: 8.58 MJ ME/kg (calculated by the formula: + g crude protein $\times 0.0129+$ g crude fat $\times 0,0420+$ g crude fibre $\times 0,0019$ $+\mathrm{g}$ N-free extracts $\times 0.0185-3.54$; Meyer and Coenen 2014)

\section{Digestible protein}

$8.70 \%$ (according to the label). Praecaecal digestible protein (pcdCP): $8.1 \%$ (calculated by the formula: pcdCP $(\mathrm{g} / \mathrm{kg})=16.19+0.746 \times \mathrm{g}$ crude protein $-0.051 \times \mathrm{g}$ NDF; Meyer and Coenen 2014)

Table values (Meyer and Coenen 2014) were used to calculate the energy and nutrient content of hay and oats and for mixed concentrates the values provided by the producers were taken. The concentrates used in the control group during the study period were either grain (mainly oats; only one horse received oats and corn flakes and one horse received oats and oil), or muesli or mash. No pelleted concentrates were used.

The energy requirement (ME) was calculated using the following equations: $\mathrm{ME}(\mathrm{MJ} / \mathrm{d})=0.52 \mathrm{MJ} \mathrm{ME} / \mathrm{kg} \mathrm{BW}^{0.75}$ and $0.4 \mathrm{MJ} \mathrm{ME} / \mathrm{kg} \mathrm{BW} 0.75$ only for the Friesian horse and the Riding Pony according to the GfE recommendations (Gesellschaft für Ernährungsphysiologie 2014). The energy requirement calculation included an adjustment for the activity level (no, light, and medium work). The assignment of the ME increments above maintenance $(0 \%, 25 \%$ and $50 \%)$ to the classifications "no", "light", and "medium" was used.

\section{Animals}

Thirty-four leisure horses with gastric lesions were selected for the study. They were presented as patients at the Tierklinik Mitterndorf between December 2014 and January 2017, with signs of colic. The horses showed abdominal pain or weight loss. A gastroscopy was performed on each horse for

Table 1 Percentages of different particle sizes of the FFD (Futtermittellabor Rosenau, Wieselburg, Austria). I Verteilung der Partikelgrößen der fett- und faserreichen Diät (FFD) angegeben in Prozent (Futtermittellabor Rosenau, Wieselburg, Austria).

\begin{tabular}{ccccccc}
\hline Diet & $>5$ & $>4$ & $>3,15$ & $>2$ & $>0.5$ & $<0.5$ \\
FFD & 82.2 & 7.8 & 4.7 & 3.5 & 1.7 & 0.1 \\
\hline
\end{tabular}


diagnostic reasons. Only mares and geldings between five and 20 years of age were enrolled in this study. During the fasting period before the gastroscopy, the horses were stabled in 3.3 × 4 m boxes with wood shavings as bedding. The horses had an average age of 11 years and an average body weight of $523 \mathrm{~kg}$. There were six mares and 28 geldings of different breeds represented as follows: 23 Warmblood horses, five Quarter Horses, two Lipizzans, one Trotter, one Noriker, one Friesian horse and one German Riding Pony.

\section{Feeding and housing}

A precise survey including the anamnesis, in particularly of feeding and keeping, was carried out by using standardized questionnaires. Only horses which received hay of adequate quality and quantity (at least $1.5 \mathrm{~kg} / 100 \mathrm{~kg}$ bodyweight) as a source of roughage were recorded. The owners had to weigh the amount of hay given per day. They also had to bring a sample and the colour, the smell, the structure, and any contamination of the hay were evaluated and classified following a scoring scale (Kamphues et al. 2014). The horses also had to be fed a concentrated feed before the start of the study. All participating horses stayed in boxes with straw $(n=21)$ or wood shavings $(n=13)$ as bedding and had access to a paddock. Horses housed in open stables or with access to grazing were excluded, since, usually, the feeding could not be adequately monitored, and a correct trial could not be guaranteed. For the calculation of the rations, the energy supply was calculated and adjusted individually for each horse with a computer program specially designed for the study. The concentrated feed was replaced by the FFD in the FFD group. In the control group, the usual concentrated feed was still used; only the required quantities were calculated and adjusted. All owners or horse keepers received a feeding plan designed for their respective horses with instructions on feeding management (quantity/meal, the order of feeding, feed). The horse owners undertook to feed nothing else than what was recommended in the feeding plan over the entire period of the study and to adhere strictly to the quantity specifications. No changes were made to the ration and the environment during the study period.

\section{Behaviour, stress and workload}

In the anamnesis, the focus was also on the nature of the horses, behavioural disorders, and possible stress situations. Symptoms, associated with gastric problems, described in existing literature, including discomfort at saddling or grooming, yawning, flehmen, poor appetite, or poor body condition were documented. The usual training and management conditions were exactly documented and had to be maintained over the entire study period without major deviations. Based on the owner's information about the use of the horse, a classification of the performance level into three categories (no, light, and medium work) followed. None of the horses worked hard. The behaviour of the horse was judged as calm and attentive, nervous, or lethargic. Only animals without other serious diseases were included in the study. Cribbing horses were excluded. The horses were not allowed to receive long-term therapies with drugs, which cause the development or worsening of the gastric ulcers (e.g. NSAID's), and anthelmintics throughout the study period.

\section{Experimental design}

Each of the 34 horses underwent gastroscopy twice. They were transported to the clinic one day before the examination. In preparation for the gastroscopy, the horses were deprived of food 12 hours before the examination. Free access to water was ensured by providing both, automatic waterers and water buckets. For the endoscopic examination, the horses were placed in an examination stand and were intravenously sedated with detomidine hydrochloride (Domidine ${ }^{\circledR} 0.01-0.02 \mathrm{mg} / \mathrm{kg}$ body weight) in combination with butorphanol (Alvegesic ${ }^{\circledR} 0.02-0.05 \mathrm{mg} / \mathrm{kg}$ body weight). The gastroscopic examinations were performed using a flexible $3 \mathrm{~m}$ videoendoscope (EVIS Olympus CF Type 100HI, OLYMPUS AUSTRIA Ges.m.b.H., Vienna). The stomach was inflated with air until its mucosal lining was smooth. The gastric contents were removed from the mucosa by flushing water through the endoscope biopsy channel. The endoscope was advanced systematically along the great curvature to the antrum pyloricum and into the proximal small intestine section to visualize the entire mucosa during each gastroscopy. All visible findings were determined according to the method described by Sykes and Jokisalo (2014). The EGUS scoring system of the Equine Gastric Ulcer Council 1999, from grades 0 to 4 (adapted by Sykes et al. 2015a), was assessed and documented. The squamous and glandular mucosa were evaluated separately. Pictures and videos were continuously taken during the evaluation. The scoring system used is shown in Table 2.

The gastroscopy was repeated, eight weeks after the first one, to check the effect of the feeding. Once enrolled in the study, the horses were randomly allocated to the FFD or control groups. To obtain as objective a result as possible, the study was performed as a blind study. The investigator who undertook all of the gastroscopic examinations and scoring remained blind to the group allocation until the scoring was com-

Table 2 The grading system for equine gastric ulcer disease adapted from EGUS Council 1999 (Sykes et al. 2015a). | Das angepasste Bewertungssystem für Magengeschwüre beim Pferd des EGUS Council 1999 (Sykes et al. 2015a).

\begin{tabular}{cc}
\hline Grade & Gastric mucosa \\
\hline I & The epithelium is intact and there is no appearance of hyperkeratosis \\
II & The mucosa is intact, but there are areas of hyperkeratosis \\
III & Small single or multifocal lesions \\
IV & Large single or extensive superficial lesions \\
\hline
\end{tabular}


pleted and recorded. Another researcher was responsible for the randomization and medication.

\section{Groups}

The 34 horses were divided into an FFD group (20/34) and a control group (14/34), after the first gastroscopy, at random by pulling slips of paper with an " $F$ " for FFD or a " $\mathrm{C}$ " for control out of a hat. All horses with EGUS $\geq 3$ ( $n=16$ FFD group, $n=9$ control group) received omeprazole at a dosage of $4 \mathrm{mg} / \mathrm{kg}$ SID for 14 days due to the severity of the disease. Omeprazole was used in this study, as a commercially formulated paste (Equinor $^{\circledR}$, Norbrook Laboratories Limited, Newry, UK). It was administered each day before the first feeding in the morning since Andrews et al. (1999) demonstrated that the administration of omeprazole in the fasting state increases its bioavailability. Each horse was weighed at the beginning and at the end of the experiment and the body condition score was documented.

\section{Statistical Analysis}

All data were collected by hand and registered using the Microsoff ${ }^{\circledR}$ Excel $^{\circledR}$ program from Windows $10^{\circledR}$. Videos and pictures were recorded and stored. To determine if there was a significant difference between the two examined groups, the Pearson's chi-squared test, the Wilcoxon-test and the MannWhitney-U-test were used. An independent t-test was performed to calculate nutrient intake (all these data were parametric; Kolmogorov-Smirnov-Test). The differences in the nutrients intake and improvement of gastric lesions between the groups as well as the correlation between EGUS and other factors such as workload, symptoms, and behaviour were established using the IBM SPSS-Software (version 23). A p-value of less than $5 \%(p<0.05)$ was considered statistically significant.

\section{Results}

\section{Feed and feeding}

Before the start of the study, the horses received between 0.5 and $5.25 \mathrm{~kg}$ concentrated feed/day. The calculated amount of starch intake per meal and per $\mathrm{kg}$ body weight exceeded $1 \mathrm{~g}$ in 18 horses, the daily ingested amount of starch was higher than $2 \mathrm{~g}$ in 19 horses and seven horses ingested almost $5 \mathrm{~g} \mathrm{starch/} / \mathrm{kg}$ body weight/day.

Before treatment, we found significant differences in the workload of the horses (median [25th /75th percentiles] FFD group 2[1/2]; control group 2[2/2]; $p=0.02)$ and starch intake (g/kg BW; FFD 1.52 $\pm 0.91 ;$ C $2.34 \pm 1.28$; $\mathrm{p}=0.04)$. The energy intake per $\mathrm{kg} \mathrm{BW}^{0.75}$ was significantly higher in the control group $(p=0.014)$ according to the higher workload. The intake of the praecaecal digestible protein $(\mathrm{pcdCP}) / \mathrm{kg}$ BW) was lower in the FFD group (FFD $1.31 \pm 0.28 ;$ C $1.70 \pm 0.49)$.

After the changeover of the ration, we had differences in the starch intake (FFD $0.09 \pm 0.05$ and C $1.38 \pm 0.62 \mathrm{~g} / \mathrm{kg} \mathrm{BW}$; $\mathrm{p}=0.00$ ), calcium content/MJ ME (FFD $0.79 \pm 0.06$; C $0.60 \pm 0.08 ; p=0.00$ ) and Ca:P-ratio (FFD 1.94 \pm 0.17 ; C $1.55 \pm 0.17 ; p=0.00)$. We found no significant difference concerning the hay intake between the groups; after the start of the study, the FFD group consumed $21.2 \mathrm{~g} / \mathrm{kg} \mathrm{BW/day} \mathrm{and}$ the control group $23.3 \mathrm{~g} / \mathrm{kg} \mathrm{BW} /$ day.

In the FFD group, the starch intake differed highly before and after the treatment $(1.52 \pm 0.91$ and $0.09 \pm 1.05 \mathrm{~g} / \mathrm{kg}$ $\mathrm{BW} /$ day, respectively). Also, the amounts of calcium and magnesium intake and the Ca-P-ratio were significantly different in the FFD group before and after the changeover (Table 3). But even in the control group, the adaptation of the rations decreased the starch intake significantly $(2.34 \pm 1.28 \mathrm{mg} / \mathrm{kg}$ BW before; $1.38 \pm 0.68$ after; $p=0.02)$.

\section{Endoscopic findings}

A complete examination of the squamous mucosa (fundus ventriculi) was possible in all 34 horses. The margo plicatus and the glandular mucosa (corpus ventriculi) could also be evaluated down to the gastric juice sea. The pylorus region could also be seen in all horses. The gastroscopic examinations were conducted and scored in real time by an experienced veterinarian. Two horses had alterations of the glandular mucosa (EGGD) only, 11 horses had alterations of the squa-

\begin{tabular}{|c|c|c|c|c|}
\hline \multicolumn{5}{|c|}{$\begin{array}{l}\text { Table } 3 \text { Mean intake of energy and nutrients } \\
\text { in beiden Gruppen vor und nach der Behandlung. }\end{array}$} \\
\hline Parameter & FFD group prior & FFD group post & Control group prior & Control group post \\
\hline Work load' & $1.40 \pm 0.75^{\mathrm{A}}$ & $1.40 \pm 0.75^{\mathrm{A}}$ & $2.07 \pm 0.48^{B}$ & $2.07 \pm 0.48^{B}$ \\
\hline MJ ME/kg BW 0.75 & $0.81 \pm 0.16^{\mathrm{A}}$ & $0.78 \pm 0.15^{A}$ & $0.97 \pm 0.19^{B}$ & $0.88 \pm 0.13^{B}$ \\
\hline Hay g/kg BW & $19.89 \pm 3.76$ & $21.2 \pm 3.54$ & $22.27 \pm 4.94$ & $23.27 \pm 5.10$ \\
\hline Fiber $\mathrm{g} / \mathrm{kg}$ BW & $5.89 \pm 1.07$ & $6.44 \pm 1.16$ & $6.78 \pm 1.62$ & $6.71 \pm 1.37$ \\
\hline Starch g/kg BW & $1.52 \pm 0.91^{\mathrm{aA}}$ & $0.09 \pm 0.05^{\mathrm{bA}}$ & $2.34 \pm 1.28^{a B}$ & $1.38 \pm 0.62^{\mathrm{bB}}$ \\
\hline Protein $^{2} \mathrm{~g} / \mathrm{kg}$ BW & $1.31 \pm 0.28^{A}$ & $1.42 \pm 0.38$ & $1.70 \pm 0.41^{\mathrm{B}}$ & $1.58 \pm 0.39$ \\
\hline Protein $^{2} \mathrm{~g} / \mathrm{MJ}$ ME & $7.74 \pm 0.73^{a}$ & $8.75 \pm 1.05^{b}$ & $8.32 \pm 1.07$ & $8.37 \pm 1.15$ \\
\hline $\mathrm{Ca} \mathrm{g} / \mathrm{kg} \mathrm{BW}$ & $0.106 \pm 0.024^{a}$ & $0.129 \pm 0.034^{b}$ & $0.119 \pm 0.027$ & $0.112 \pm 0.019$ \\
\hline 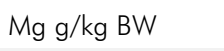 & $0.038 \pm 0.012$ & $0.042 \pm 0.009$ & $0.045 \pm 0.012$ & $0.042 \pm 0.011$ \\
\hline Ca:P & $1.62 \pm 0.24^{a}$ & $1.94 \pm 0.17^{\mathrm{bA}}$ & $1.52 \pm 0.24$ & $1.55 \pm 0.17^{B}$ \\
\hline
\end{tabular}

Data expressed as mean $\pm S D ;{ }^{1} 1$ no work, 2 light work, 3 medium work; ${ }^{\text {ab }}$ difference before-after treatment; ${ }^{\mathrm{AB}}$ difference between the two groups; $\mathrm{BW}$

body weight; ${ }^{2}$ precaecal digestible protein 
mous mucosa (ESGD), only and 21 horses had lesions in both regions. All 20 horses in the FFD group had lesions of the squamous mucosa. In the control group, 12 out of the 14 horses (85.7\%) had lesions and two horses (14.3\%) showed no lesions in this region. Thirteen horses $(65 \%)$ in the FFD group and 10 horses (71.4\%) in the control group showed lesions in the glandular mucosa. Figure 1 shows the number of horses with lesions in the two regions in a bar chart.

Table 4 shows the number of horses with lesions in the different regions of the stomach (dorsal squamous fundus, margo plicatus, ventral glandular fundus, antrum and pylorus) in detail.

Table 5 shows the median lesion scores of the squamous and glandular region for both groups at the first and second gastroscopy. In the squamous region, the median (25th/75th

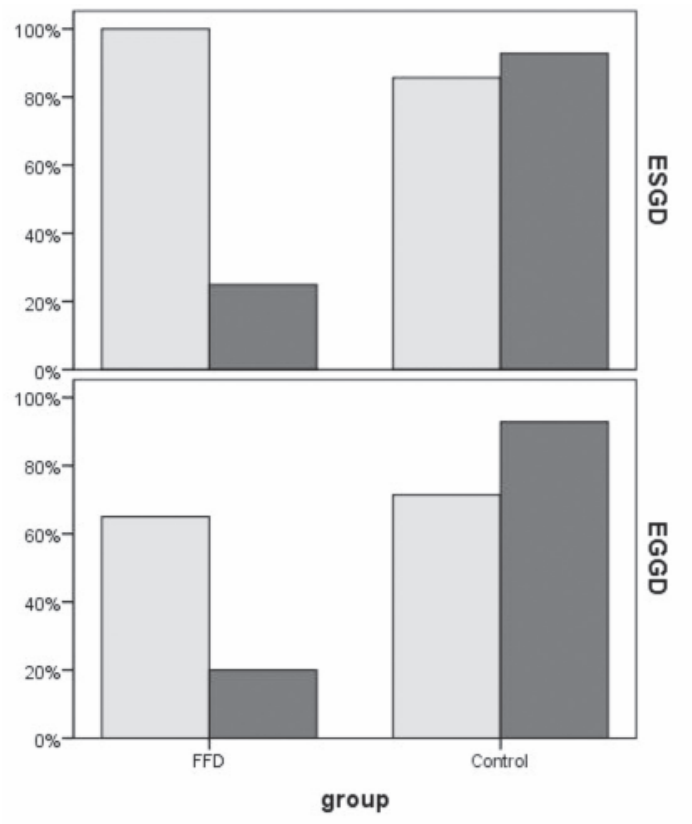

Fig. 1 Bar chart of the number of horses (in \%) with lesions (EGUS-Grade 1-4) in the squamous and glandular region of the stomach before and after treatment. Squamous region: FFD group 20/5* (100\%/25\%); Control group 12/13* (85,7\%/92,9\%). Glandular region: FFD group 13/4* (65\%/ 20\%); Control group 10/13* $(71,4 \% / 92,9 \%)$. *Number of horses (before treatment (prior)/after treatment(post)). | Säulendiagramm mit Angabe der Anzahl der Pferde (in \%) mit Läsionen (EGUS-Grad 1-4) im Bereich der kutanen und glandulären Magenschleimhaut vor und nach der Behandlung. Kutane Schleimhaut: FFD Gruppe 20/5* (100\%/25\%); Kontrollgruppe 12/13* (85,7\%/92,9\%). Glanduläre Schleimhaut: FFD Gruppe 13/4* (65\%/ 20\%); Kontrollgruppe 10/13* (71,4\%/92,9\%). *Anzahl der Pferde (vor der Behandlung (prior)/nach der Behandlung (post). percentiles) lesion score was $3(2 / 3.8)$ before and $0(0 / 0.8)$ after the treatment in the FFD group $(p=0.000)$, and $2(2 / 3.3)$ before and $3(1.8 / 3)$ after the treatment in the control group $(p=0.832)$. In the glandular region, the median lesion score was $1.5(0 / 3)$ before and $0(0 / 0)$ after the treatment in the FFD group $(p=0.001)$, and $2(0 / 3)$ before and $1(1 / 2)$ after the treatment in the control group $(p=0.642)$.

Figure 2 shows the change in the median lesion scores for both groups in a box and whisker plot. It shows that the grade of gastric ulcers in the FFD group significantly improved in both areas of the stomach. In the FFD group, the squamous mucosa improved in five (25\%) horses and 15 (75\%) horses had a total healing. The glandular mucosa improved in three $(15 \%)$ horses while a total healing was seen in 10 (50\%) horses, while seven (35\%) horses had no lesions in this area.

In the control group, the squamous mucosa improved in two $(14.3 \%)$ and worsened in four $(28.6 \%)$ horses, and one (7.1\%) horse had no lesions in this area. The glandular mucosa improved in six (42.9\%) horses, there was no change

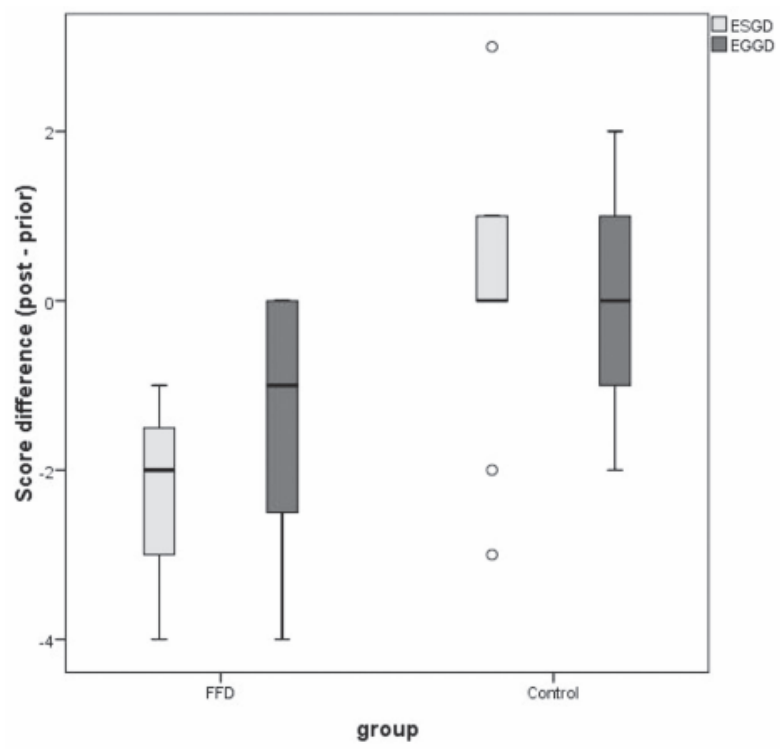

Fig. 2 Box and whisker plot demonstrating median (continuous line), interquartile ranges (represented by outer edges of box) and ranges (error bars) of the differences in the scores of the squamous region (ESGD) and the glandular region (EGGD) of the stomach (post-prior treatment) in both groups (FFD and control). I Boxplot Diagramm mit Median (durchgezogene Linie), Interquartilsabstand (äußere Kanten der Box) und Spannweite (Whiskers) zur Änderung im EGUS-Score der kutanen (ESGD) und der glandulären (EGGD) Magenschleimhaut von Therapie- und Kontrollgruppe im Vergleich vor und nach der Therapie.

Table 4 Number of horses with lesions in the different stomach regions in detail in both groups before and after treatment. / Anzahl der Pferde mit Läsionen in den unterschiedlichen Magenregionen im Detail in beiden Gruppen vor und nach der Behandlung.

\begin{tabular}{lcccc}
\hline Group & \multicolumn{2}{c}{ Squamous region } & \multicolumn{2}{c}{ Glandular region } \\
\hline & $14 / 2$ & Margo plicatus & Ventral glandular fundus & Antrum and Pylorus \\
\cline { 2 - 5 } FFD group & & $18 / 3$ & $2 / 0$ & $13 / 4$ \\
$(\mathrm{~N}=20)$ & $3 / 5$ & $12 / 13$ & $1 / 0$ & $10 / 13$ \\
Controlgroup & & & \\
$(\mathrm{N}=14)$ & & & \\
\hline
\end{tabular}


Table 5 EGUS-Grading of the squamous region (ESGD) and the glandular region (EGGD) in both groups before and after treatment. | EGUSGrading der kutanen Magenschleimhaut (ESGD) und der glandulären Magenschleimhaut (EGGD) in beiden Gruppen vor und nach der Behandlung.

\begin{tabular}{lcccc}
\hline \multicolumn{3}{c}{ ESGD } & & \\
\hline Group & Before treatment & after treatment & Before treatment & after treatment \\
FFD & $3(2 / 3.75)$ & $0(0 / 0.75)$ & $1.5(0 / 3)$ & $0(0 / 0)$ \\
$(\mathrm{N}=20)$ & & & & $1(1 / 2)$ \\
Control & $2(2 / 3.25)$ & $3(1.75 / 3)$ & $2(0 / 3)$ & \\
$(\mathrm{N}=14)$ & & & & \\
\hline
\end{tabular}

Data expressed as median $\left(25^{\text {th }} / 75^{\text {th }}\right.$ percentiles $)$

in two (14.3\%) horses, and worsened in five (35.7\%) horses, while one $(7.1 \%)$ horse had no lesions in this area.

\section{Body weight}

The average body weight $( \pm \mathrm{SD})$ of the 34 horses was $526 \pm 77 \mathrm{~kg}$. The lightest horse weighed $358 \mathrm{~kg}$ at the beginning; the heaviest horse weighed $697 \mathrm{~kg}$. The horses in the FFD group gained weight during the study, in contrast to the horses in the control group. The horses in the control group even lost weight. At the time of the first examination, the horses in the FFD group had an average body weight of $536 \mathrm{~kg}$; the horses in the control group weighed $512 \mathrm{~kg}$ on the average. However, at the time of the second gastroscopy, the horses in the FFD group had an average body weight of $557 \mathrm{~kg}$, while the horses in the control group weighed $510 \mathrm{~kg}$.

\section{Body condition score}

The body condition score from Henneke et al. (1983), ranging from one to nine, was used in this study. The participating horses had a body condition score (BCS) between 3/9 and 5/9. The horses in the FFD group showed a slight improvement in the average nutritional status from a median (25th/75th percentiles) BCS of $4(4 / 5)$ to a BCS of $5(4 / 5)$ $(p=0.004)$. The horses in the control group changed from a median BCS of $4.5(4 / 5)$ to $4(4 / 5)(p=0.56)$. From a total of 13 horses with a poor body condition $(B C S<5)$ in the FFD group, the BCS of eight horses improved by one degree. In the control group, only one horse from a total of seven horses $(B C S<5)$ had improved by one degree, five horses remained unchanged, and the score even deteriorated in one horse (BCS 4 to BCS 3). Neither at the beginning of the study a difference due to the body condition scores could be found between the groups $(p=0.69)$, nor after the treatment $(p=s 0.10)$, although a slight trend could be observed.

\section{Discussion}

The aetiology and therapy of EGUS have already been discussed in many studies. But there are few studies on the preventive measures, especially the influence of feeding. The research for the methods to treat or prevent gastric ulcers effectively, without using expensive pharmaceutical agents is a new trend in veterinary medicine (Bonelli et al. 2016, Sutton 2016). To meet this growing need, this study aimed to evaluate the effectiveness of a change in the feeding regime as a part of the treatment of EGUS in adult horses. The positive effects of the ingredients of the tested feed on the gastrointestinal tract are well known. Alfalfa is rich in protein and calcium and is, therefore, often recommended for its buffering properties, to prevent gastric lesions (Vondran et al. 2017). In rats, the basal secretion of gastric acid was inhibited when a high-calcium diet was fed (Fisher et al. 1990). The same effect was seen in horses fed an alfalfa hay-grain diet (Nadeau et al. 2000). Also, high amounts of protein can act as a buffer against acidity and therefore plays a major role in ulcer formation (Cleave 1974), as previously seen on other studies in horses (Nadeau et al. 2000) and cattle (Haaland et al. 1982).

Milk thistle has an anti-inflammatory and antiulcerogenic effect. Dandelion has an appetizing and a secretory effect on the upper gastrointestinal tract and helps with dyspeptic disorders. Linseed has anti-inflammatory effects due to the high content of n-3-fatty acids and protects the mucous membrane of the stomach (Aichberger et al. 2006).

Cargile et al. (2004) described a positive effect for the treatment and prevention of gastric ulceration by the addition of corn oil (linoleic acid) to decrease the gastric acid output and increase the prostaglandin E2 and sodium production. The tested FFD contains linolenic acid in the linseed oil and linoleic acid in the milk thistle oil. Fat increases the secretion of bicarbonate-rich mucus (Cargile et al., 2004). The horses that were fed the FFD had a longer ingestion time (mean feeding time 10:29 min for $500 \mathrm{~g}$ ), due to the rich structure of the feed because of the addition of lignocellulose. To ingest $1 \mathrm{~kg}$ oats, horses need only around 10 minutes (Meyer and Coenen 2014). A positive effect is the increased saliva production while chewing, which buffers the gastric acid. Saliva contains bicarbonate, which acts to neutralize the acidity of the gastric juices and so, helps to protect the gastric mucosa from its corrosive effects (Hepburn 2016). Saliva production is related to the particle structure of the diet; for example, feeding of $1 \mathrm{~kg}$ of hay results in 3 to $6 \mathrm{~L}$ of saliva production, while feeding $1 \mathrm{~kg}$ of grain results in 1 to $1.7 \mathrm{~L}$ of saliva production in adult horses (Meyer et al. 1986, Vondran et al. 2016). The content of starch in the FFD is very low (4.6\%). Gastric ulcers are often caused by a diet rich in concentrated starchy feed but poor in structure, which leads to an acid intragastric $\mathrm{pH}$. Unphysiological long-lasting $\mathrm{pH}$ values of $\leq 2$ and prolonged exposure of the pars glandularis and the pars nonglandularis to gastric acid are thought to be ulcerogenic (Reese and Andrews 2009, Damke et al. 2015).

The results of Fedtke et al. (2015) show that the particle size of the feed may also play a role in ulcer development. They found that foals fed alfalfa chaff had a significantly higher lesion score especially in the pyloric region, compared to 
foals fed hay or a total mixed ration. They assumed that alfalfa chaff induced lesions probably due to mechanical injury to the mucosa, as the pyloric region is an area of the stomach with high motility. These findings were similar to those of other authors studying weanlings and adult horses (Vondran et al. 2016, Vondran et al. 2017). As the horses of the control group received either oats or muesli it is not likely that the grounding of the concentrate or the FFD influenced the outcome. The particle size of the FFD was lower than of the oats and possibly, similar to that of the muesli or mash.

Our results showed a significant ulcer improvement in the horses in the FFD group. 35\% of the treated horses showed an improvement and $65 \%$ showed a total healing of the ulcers. There was no horse without a change or with deterioration in the EGUS score. In contrast, 14.3\% horses of the control group showed an improvement of the ulcers. No horse in this group showed a total healing. $71.4 \%$ showed no change of score and $14.3 \%$ even got worse.

In this study, the healing rate of the FFD group horses was higher than in similar studies (Bonelli et al. 2016). We only used horses with EGUS grade 2 or higher because of the higher clinical relevance of the disease at a severity score $\geq 2$. In this study, no correlation was found between age or sex and the EGUS severity score. Further, the score severity was not significantly related to workload, behaviour or stabling (straw or wood shavings as a bedding) and no significant correlation was found between the gastric score severity and the typical symptoms described previously in the existing literature (Ehlers et al. 2016, Andrews and Nadeau 1999). These results are in line with the findings reported by Hepburn (2014) in a large study of sport and leisure horses in the UK. In contrast, a study on thoroughbred racehorses identified sex, trainer, no grass turnout, direct contact to each other, and heavy work as the risk factors for squamous ulceration (Habershon-Butcher et al. 2012).

During diet calculation, we found out that 12 horses in our study had received too high amounts of grain before the study period ( $>2 \mathrm{~g}$ starch/ $\mathrm{kg}$ bodyweight/day). The results obtained by Luthersson et al. $(2009 a, b)$ in Denmark clearly show that the amount of starch fed per day or per meal is a very important factor in ulcer development. This type of feed increases the acidity of the gastric content due to the volatile fatty acids derived from the intragastric fermentation of the ingested soluble carbohydrates. It may also reduce hay uptake, which limits the production of the buffering saliva (Tamzali et al. 2011 , Nadeau et al., 2000, 2003a,b).

In the present study, the other 22 horses developed gastric ulcers although the starch content in the ration was lower than $2 \mathrm{~g} / \mathrm{kg}$ body weight/day. As there was no correlation with the workload, other environmental factors may have played a role. According to Luthersson et al. (2009b), water deprivation at the paddock or more than $1 \mathrm{~g}$ starch intake/meal increase the risk of gastric ulcers as well. After changing the ration, the starch content in the FFD group was very low and given the protective substances in the FFD and the high amount of hay the horses received, a positive outcome was as expected. However, the fact that the horses of the control group did not or hardly improve was not expected, because the starch in the adapted rations was lower than $2 \mathrm{~g} / \mathrm{kg}$ body weight/day and the amount of hay was even higher than in the FFD group and twice as much as calculated for racehorses in Turkey by Kaya et al. (2018). Obviously, there may be factors which we could not observe in this study like humananimal interactions which may influence the outcome of gastric ulcers in horses. Nevertheless, the intake of starch or grain seems to be the most important parameter concerning the outcome for horses suffering from EGUS.

The fasting procedure in this study was sufficient to enable the gastric mucosa and the pylorus to be evaluated fully in all horses. However, it is not possible to guarantee that all small lesions were seen (Andrews et al. 2002). As has been found in the previous studies, most of the lesions were found adjacent to the margo plicatus (Luthersson et al. 2009a). Out of the 34 horses in this study, 30 (88.2\%) had lesions in this region and $23(67.6 \%)$ had lesions around the pylorus. In our study, the incidence of lesions at the pylorus is higher than described in the literature but maybe, that is because a lot of other studies did not evaluate this region of the stomach (Chameroy et al. 2006, Luthersson et al. 2009a, Marqueset al. 2011 ).

One limitation when comparing the studies on EGUS in horses, is the classification of ulcers, in particularly, the severity level used to define the presence or absence of ulceration (Luthersson et al. 2009a). Different studies use different scoring systems to describe the ulcers, which makes a comparison difficult. In order to enable a comparison with future studies, in the current study, the EGUS scoring system of the Equine Gastric Ulcer Council (1999), from grades 0 to 4, was used for describing the gastric lesions as recommended by Sykes et al. (2015a). We analysed the squamous and glandular region independently to enable the identification of the risk factors for each anatomical type of lesion, as recommended by Luthersson et al. (2009a).

In our study, the horses in the control group hardly improved and even got worse EGUS severity scores, although they had received omeprazole in the recommended dosage over the first 14 days after the first gastroscopy. An administration for 14 days has been proven effective at the Tierklinik Mitterndorf for the treatment of EGUS in previous cases. It was found that the gastric lesions of most of the horses were cured by that time. However, the manufacturer's recommendation is the administration of it for at least 21 days. In order to check the success of the medication with omeprazole in the current study, another gastroscopy had to be carried out after the first two weeks since we didn ' $t$ know whether the ulcers did not improve or if they became worse when the medication was stopped.

The poor results only in the control group are another argument for the possibility that full grain may play an important role in ulcer development and healing since there was no other difference between the two groups. This is also confirmed by the significant difference in the EGUS score severity between the groups.

\section{Conclusion}

Feeding a high-fibre and high-fat diet seems to be highly effective for the improvement of gastric lesions. Thus, further 
studies are needed to verify whether a prolonged administration will help to prevent a recurrence of gastric lesions in the horses at risk. The equine veterinarians may take into consideration full grain diets as a potential cause of EGUS in horses and thus, change the diet to a grain-free, fibre- and fatenriched diet.

\section{Acknowledgements}

The author gratefully acknowledges Mühldorfer Nutrition AG for supporting this study. Also, the horse owners who participated in this study are thanked for their support.

\section{Animal Welfare Statement}

The experimental protocol was discussed and approved by the institutional ethics and animal welfare committee of the University of Veterinary Medicine Vienna in accordance with the Good Scientific Practice guidelines and the national legislation.

\section{Conflict of interest statement}

The authors disclose no conflict of interest.

\section{References}

Aichberger L., Bizaj M., Fritsch F., Gansinger D., Hagmüller W., Hahn I., Hozzank A., Kolar V., Stöger E. (2006) Kräuter für Nutzund Heimtiere. Ratgeber für die Anwendung ausgewählter Heilund Gewürzpflanzen. Eigenverlag, 2. aktualisierte Auflage 2012; ISBN 978-3-200-02690-2

Andrews F. M., Nadeau J. A. (1999) Clinical syndromes of gastric ulceration in foals and mature horses. Equine Vet. J. Suppl.29, 3033; DOI 10.1111/i.2042-3306.1999.tb05165.x

Andrews F. M., Sifferman R. L., Bernard W., Hughes F. E., Holste J. E., Daurio C. P., Alva R., Cox J. L. (1999) Efficacy of omeprazole paste in treatment and prevention of gastric ulcers in horses. Equine Vet. J. Suppl.29, 81-86; DO110.1111/i.2042-3306.1999. tb05176.x

Andrews F. M., Reinemeyer C. R., McCracken M. D., Blackford J. T., Nadeau J. A., Saabye L., Sotell M., Sacton A. (2002) Comparison of endoscopic, necropsy and histology scoring of gastric ulcers. Equine Vet. J. 34, 475-478; DOI 12358050

Aranzales J. R. M., Cassou F., Andrade B. S. C., Alves G. E. S (2012) Presence of gastric ulcer syndrome in equine from the military police. Arch. Med. Vet.44, 185-189; DOI S0301-732X2012000 200013

Bell R. J., Kingston J. K., Mogg T. D., Perkins N. R. (2007) The prevalence of gastric ulceration in racehorses in New Zealand. N. Z. Vet. J. 55, 13-18; DOI10.1080/00480169.2007.36729

Bonelli F., Busechian S., Meucci V., Caporrino G., Briganti A., Rueca F., Zappulla F., Ferini E., Ghiandai L. (2016) pHyloGASTRO in the Treatment of Equine Gastric Ulcer Lesions. J. Equine Vet. Sci.46, 69-72; DOI http://dx.doi.org/10.1016/i.jevs.2016.06.069

Cargile J., Burrow J., Kim I. (2004) Effect of dietary corn oil supplementation on equine gastric fluid acid, sodium, and prostaglandinE2contentbeforeandduringpentagastrininfusion. J. Vet. Intern. Med. 18, 545-549; DOI 10.1111/i.1939-1676.2004. tb02583.x Chameroy K. A., Nadeau J. A., Bushmich S. L., Dinger J. E., Hoagland T. A., Saxton A. M. (2006) Prevalence of Non-Glandular Gastric Ulcers in Horses Involved in a University Riding Program. J. of Equine Vet. Sci.26(5) 207-211; DOlhttp://dx.doi.org/ 10.1016/i.jevs.2006.03.001
Cleave T. L. (1974) Peptic Ulcer. In: The saccharine disease. Ed: John Wright, Bristol, UK, 138-174; ISBN 0723603685

Dahlkamp M., Feige K., Venner M. (2012) Incidence of gastric ulcers in weanling foals and the treatment with omeprazole. Pferdeheilkunde 28,561-569; DOI 10.21836/PEM20120506

Damke C., Snyder A., Uhlig A., Coenen M., Schusser G. M. (2015) Impact of diet on 24-hour intragastric $\mathrm{pH}$ profile in healthy horses. Berl. Münch. Tierärztl. Wochenschr. 128, 35-39; DOI 10.276/ 0005-966-128-35

Dionne R. M., Vrins A., Doucet M. Y., Pare J. (2003) Gastric ulcers in standardbred racehorses: prevalence, lesion description and risk factors. J. Vet. Intern. Med.17, 218-222; DOl10.1111/i. 1939-1676.2003.tb02437.x

Ehlers K., Uhlig A., Recknagel S., Snyder A., Brever J., Arnold C., Graneß N., Schusser G. F. (2016) Schleimhautläsionen im Bereich des Pylorus - Retrospektive Studie an 315 Pferdepatienten (20042013). Pferdeheilkunde 32, 96-102; DOI 10.21836/PEM2016 0201

Fedtke A., Pfaff M., Volquardsen J., Venner M., Vervuert I. (2015) Effects of feeding different roughage-based diets on gastric mucosa after weaning in warmblood foals. Pferdeheilkunde 31, 596602; DOI 10.21836/PEM20150607

Fisher H., Kaufman R. H., Hsu H. C., Kasziba K., Farmanfarmaian A., Flancbaum L. J. (1990) Inhibition of gastric acid secretion in the rat by high calcium. Nutr. Res.10, 1441-1453; ISSN: 0271-5317

Gesellschaft für Ernährungsphysiologie (2014) Empfehlungen zur Energie- und Nährstoffversorgung von Pferden (Energie- und Nährstoffbedarf landwirtschaftlicher Nutztiere). DLG Verlag, Frankfurt, Germany. ISBN 978-3769008050

Haaland G., Tyrrell H., Moe P., Wheeler W. (1982) Effect of crude protein level and limestone buffer in diets fed at two levels of intake on rumen $\mathrm{pH}$, ammonia-nitrogen, buffering capacity and volatile fatty acid concentration in cattle. Anim. Sci. 55, 943-950; DOI 10.2527/jas 1982.554943x

Habershon-Butcher J. L., Hallowell G. D., Bowen I. M., Sykes B. W. (2012) Prevalence and risk factors for ulceration of the gastric glandular mucosa in Thoroughbred racehorses in training in the UK and Australia. J. Vet. Int. Med. 26, 731; DOI 10.1111/j.1939-1676.2012.00937.x

Hammond C. J., Mason D. K., Watkins K. L (1986) Gastric ulceration in mature thoroughbred horses. Equine Vet. J. 18, 284-287; DOI 10.1111/j.2042-3306.1986.tb03629.x

Hellings I. R., Larsen S. (2014) ImproWin ${ }^{\circledR}$ in the treatment of gastric ulceration of the squamous mucosa in trotting racehorses. Acta Vet. Scand. 56, 13; DOl https://doi.org/10.1186/1751-0147-56-13

Hepburn R. J. (2014) Treatment of ulceration of the gastric glandular mucosa: Retrospective evaluation of omeprazole and sucralfate combination therapy in 204 sport and leisure horses. 11th International Equine Colic Research Symposium, 7.-10. Juli 2014, Dublin, Ireland, 108-109

Hepburn R. J. (2016) Gastric ulceration in horses. Equine Pract. 33, 116-124; DOI 10.1136/inp.d1 195

Huff N. K., Auer A. D., Garza F. Jr, Keowen M. L., Kearney M. T., McMullin R. B., Andrews F. M. (2012) Effect of Sea Buckthorn Berries and Pulp in a Liquid Emulsion on Gastric Ulcer Scores and Gastric Juice pH in Horses. J. Vet. Intern. Med. 26, 1186-1191; DOI 10.1111/j.1939-1676.2012.00975.x

Jonsson H., Egenvall A. (2006) Prevalence of gastric ulceration in Swedish Standardbreds in race training. Equine Vet. J. 38, 209213; DOI 10.2746/042516406776866390

Kamphues J., Coenen M., Wolf P., Liesegang A., Eder K., Männer K., Iben C., Zebeli Q., Kienzle E., Zentek J. (2014) Supplemente zur Tierernährung für Studium und Praxis. 14thEd., M.\& H. Shaper, Hannover, Germany, 183. ISBN 978-3-7944-0240-3.

Kaya-Karasu G., Huntington P., Iben C., Murray J. A. (2018) Feeding and management practices for racehorses in Turkey. J. Equine Vet. Sci. 61, 108-113; DOI: 10.1016/i.jevs.2017.04.009

Luthersson N., Nielsen K. H., Harris P., Parkin T. D. H. (2009a) The prevalence and anatomical distribution of equine gastric ulceration syndrome (EGUS) in 201 horses in Denmark. Equine Vet. J. 41, 619-624; DOI19927578 
Luthersson N., Nielsen K. H., Harris P., Parkin T. D. H. (2009b) Risk factors associated with equine gastric ulceration syndrome (EGUS) in 201 horses in Denmark. Equine Vet. J.41, 625-630; DOI 10.2746/042516409X441929

Marques F. J., Epp T., Wilson D., Ruiz A. J., Tokatelloff N., Manning S. (2011) The prevalence and risk factors of osophageal and nonglandular gastric leasions in Thoroughbred racehorses in Saskatchewan. Equine Vet. Educ. 23, 249-254; DOl10.1111/i. 2042-3292.2010.00175.x

Merritt A. M. (2009) Appeal for proper usage of the term "EGUS": Equine gastric ulcer syndrome. Equine Vet. J. 41, 616; DOI $10.2746 / 042516409 \times 454574$

Meyer H., Coenen M. (2014) Pferdefütterung. 5th Ed., Enke, Stuttgart, Germany. ISBN 978-3-8304-1095-9

Meyer H., Coenen M., Probst D. (1986) Beiträge zur Verdauungsphysiologie des Pferdes: Futtereinspeichelung und -passage im Kopfdarm des Pferdes. J. Anim. Physiol. Anim. Nutr. 56, 171-183; DOI: 10.1111/j.1439-0396.1986.tb00561.x

McClure S. R., Carithers D. S., Gross S. J., Murray M. J. (2005) Gastric ulcer development in horses in a simulated show or training environment. J. Am. Vet. Med. Assoc. 227, 775-777; DOI 16178400

Murray M. J., Grodinsky C., Anderson C. W., Radue P. F., Schmidt G. $R$. (1989) Gastric ulcers in horses: a comparison of endoscopic findings in horses with and without clinical signs. Equine Vet. J. 21, 68-72. PMID: 9118110

Murray M. J., Schusser G. F., Pieper F. S., Gross S. J. (1996) Factors associated with gastric lesions in thoroughbred race horses. Equine Vet. J. 28, 368-374; DOI: 10.1111/j.2042-3306.1986.tb 03629.x

Murray M. J. (2009) Diseases of the stomach. In: Large Animal Internal Medicine, Ed: B.P. Smith, Mosby Elsevier, St Louis. 695-702; ISBN 978-0-323-08839-8

Nadeau J. A., Andrews F. M., Mathew A. G., Argenzio R. A., Blakkford J. T., Sohtelli M., Saxton A. M. (2000) Evaluation of diet as a cause of gastric ulcers in horses. Am. J. Vet. 61, 784-790; DOI 10895901

Nadeau J. A., Andrews F. M., Patton C. S., Argenzio R. A., Mathew A. G., Saxton A. M. (2003a) Effects of hydrochloric, acetic, butyric, and propionic acids on pathogenesis of ulcers in the nonglandular portion of the stomach of horses. Am. J. Vet.Res. 64, 404412.; DOI 12693528

Nadeau J. A., Andrews F. M., Patton C. S., Argenzio R. A., Mathew A. G., Saxton A. M. (2003b) Effects of hydrochloric, valeric, and other volatile fatty acids on pathogenesis of ulcers in the nonglandular portion of the stomach of horses. Am. J.Vet.Res. 64, 413417, DOI 12693529

Nadeau J. A., Andrews F. M. (2009) Equine gastric ulcer syndrome: The continuing conundrum. Equine Vet. J. 41, 611-615; DOI 10.2746/042516409X468056

Niedzwiedz A, Kubiak K., Nicpon J. (2013) Endoscopic findings of the stomach in pleasure horses in Poland. Acta. Vet. Scand. 55, 45; DOI 10.1186/1751-0147-55-45

Reese R. E., Andrews F. M. (2009) Nutrition and dietary management of equine gastric ulcer syndrome. Vet. Clin. North. Am. Equine Pract. 25, 79-92; DOI 10.1016/i.cveq.2008.11.004.

Sanz M. G., Vilioen A., Saulez M. N., Olorunju S., Andrews F. M. (2014) Efficiency of a pectin-lecithin complex for treatment and prevention of gastric ulcers in horses. Vet. Rec.175, 147; DOI 10.1136/vr. 102359

Sutton D. (2016) Equine gastric ulceration syndrome: treatment and prevention. Vet. Rec. 175, 145-146; DOI dx.doi.org/10.1136/ vr.g4613

Sykes B. W., Jokisalo J. M. (2014) Rethinking equine gastric ulcer syndrome: Part 1 - Terminology, clinical signs and diagnosis. Equine Vet. Educ. 26, 543-547; DOI 10.1111/eve.12236

Sykes B. W., Sykes K. M., Hallowell G. D. (2014a) A comparison between pre- and post exercise administration of omeprazole in the treatment of equine gastric ulcer syndrome: A blinded, randomised, clinical trial. Equine Vet. J.46, 422-426; DOI 10.1111/evi. 12083

Sykes B. W., Sykes K. M., Hallowell G. D. (2014b) Efficacy of a Combination of Apolectol, Live Yeast (Sacchaomyces cerevisiae [CNCM I-1077]), and Magnesium Hydroxide in the Management of Equine Gastric Ulcer Syndrome in Thoroughbred Racehorses: A Blinded, Randmised, Placebo-Controlled Clinical Trial. J. Equine Vet. Sci. 34, 1274-1278; DOI http://dx.doi.org/10.1016/i.jevs. 2014.09 .006

Sykes B. W., Sykes K. M., Hallowell G. D. (2014c) Comparison of effect of two doses of omeprazole on the squamous gastric mucosa in thoroughbred racehorses. Vet. Rec.175, 249; DOI $10.1136 / v r .102622$

Sykes B. W, Jokisalo J. M. (2015) Rethinking equine gastric ulcer syndrome: Part 3 - Equine glandular gastric ulcer syndrome (EGGUS). Equine Vet. Educ. 27, 372-357; DOI 10.1111/eve. 12287

Sykes B. W., Hewetson M., Hepburn R. J., Luthersson N., Tamzali Y. (2015a) European College of Equine Internal Medicine Consensus Statement-Equine Gastric Ulcer Syndrome in Adult Horses. J. Vet. Intern. Med. 29, 1288-1299; DOI 10.1111/jvim. 13578

Sykes B. W., Sykes K. M., Hallowell G. D. (2015b) A comparison of three doses of omeprazole in the treatment of equine gastric ulcer syndrome: A blinded, randomised, dose-response clinical trial. Equine Vet. J. 47, 285-290; DOI 10.1111/evj.1228

The Equine Gastric Ulcer Council (1999) Recommendations for the diagnosis and treatment of equine gastric ulcer syndrome (EGUS). Equine Vet. Educ. 11, 262-272; DOI 10.1111/i.2042-3292. 1999.tb00961.x

Tamzali Y., Marguet C., Priymenko N., Lyazrhi F. (2011) Prevalence of gastric ulcer syndrome in high-level endurance horses. Equine Vet. J. 43, 141-144; DOI 10.1111/i.2042-3306.2010. $00129 . x$

Vatistas N. J., Snyder J. R., Carlson G. P., Johnson B., Arther R. M., Thurmond M., Lloyed K. C. K. (1994) Gastric-ulceration in racing thoroughbreds - A pathological and epidemiologic study. Gastroenterol. 106, A848-A848; ISSN: 0016-5085

Venner M., Lauffs S., Deegen E. (2001) Einfluss von Pronutrin ${ }^{\circledR}$ auf Magenschleimhautläsionen beim erwachsenen Pferd. Pferdeheilkunde 17, 3-10; DOI 10.21836/PEM20010101

Vondran S., Venner M., Vervuert I. (2016) Effects of two alfalfa preparations with different particle sizes on gastric mucosa in weanlings: alfalfa chaff versus alfalfa pellets. BMC Vet. Res. 12, 110; DOI 10.1186/s12917-016-0733-5

Vondran S., Venner M., Coenen M., Vervuert I. (2017) Effects of alfalfa chaff on gastric mucosa in adult horses. Pferdeheilkunde 33, 66-71; DOI 10.21836/PEM20170109 